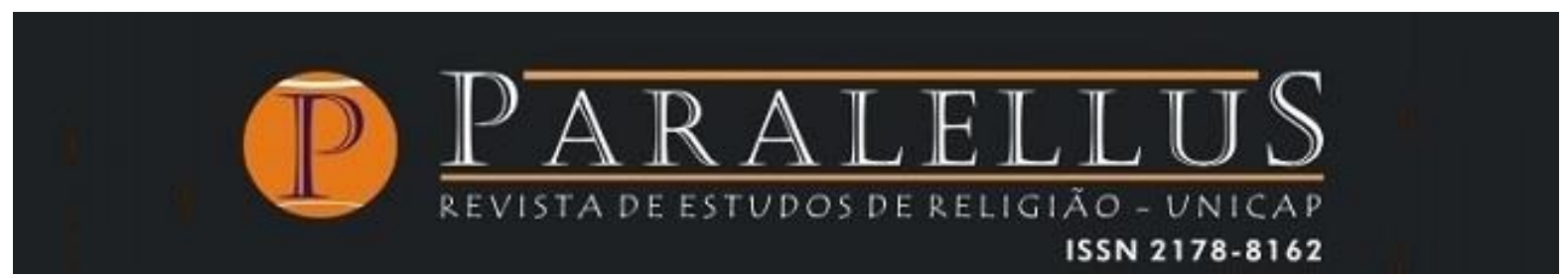

Volume 12 - Número 30

DOSSIÊ: INTERPRETAÇÃO PLURALISTA DAS RELIGIÕES

doi: 10.25247/paralellus.2021.v12n30.p449-467

\title{
SOBRE CAMELOS E AGULHAS: NOTAS SOBRE A HISTÓRIA DE UM DITO ATRIBUÍDO A JESUS
}

\author{
ABOUT CAMELS AND NEEDLES: NOTES ON THE HISTORY OF A SAYING \\ ATTRIBUTED TO JESUS
}

Pedro Lima Vasconcellos

\section{Resumo}

O artigo traz à tona um dito atribuído a Jesus, que faz uso da imagem de um camelo em relação ao fundo de uma agulha para afirmar a prática impossibilidade de uma pessoa rica entrar no reino de Deus. Discute reações que ele suscitou, desde sua inserção em narrativas que o associaram a uma situação específica até movimentos hermenêuticos que lhe deram outras significações, trataram de lhe atenuar o impacto ou o reescreveram com outro enquadramento. Para tanto são comentados relatos presentes no Novo Testamento, literatura relacionada aos chamados "padres da Igreja" e uma passagem hoje encontrada no Corão muçulmano. Com isto se mostra o incômodo da imagem e do dito transmitido como sendo de Jesus em gerações que sofreram seu impacto. O percurso proposto joga luzes sobre uma temática sempre sensível quando se pensam as relações entre religiões e sociedades: a da riqueza, sua posse e usufruto.

Palavras-chave: Riqueza, parábola do camelo e da agulha, evangelhos sinóticos, escritos patrísticos, Corão.

\section{ABStRACT}

The article brings up a saying attributed to Jesus, which makes use of the image of a camel in relation to the bottom of a needle to affirm the practical impossibility of a rich person entering the kingdom of God. It discusses the reactions that it provoked, from its insertion in narratives

\footnotetext{
" Professor da Unidade Educacional Palmeira dos Índios e do Programa de Pós-Graduação em História da Universidade Federal de Alagoas. Mestre e livre-docente em Ciências da Religião, doutor em Ciências Sociais e pós-doutor em História.
} 
that associated it with a specific situation to hermeneutical movements that gave it other meanings, tried to soften its impact or rewrote it with another framework. To this end, accounts present in the New Testament, literature related to the so-called "Church Fathers" and a passage found today in the Muslim Qur'ān are commented on. This shows the discomfort of the image and the saying transmitted as being of Jesus in generations that have suffered its impact. The proposed route sheds light on an issue that is always sensitive when thinking about relations between religions and societies: that of wealth, its possession and enjoyment.

Keywords: Wealth, Parable of the camel and the needle, Synoptic Gospels, Patristic Writings, Qur'ān.

\section{INTRODUÇÃO}

No início eram duas figuras, aproximadas para formarem uma imagem improvável e mesmo absurda, que ao ser delineada deve surpreender, fazer rir ou, quem sabe, pelo menos suscitar alguma inquietação: um camelo passando pelo fundo de uma agulha: aquele "é o animal mais volumoso do Oriente Próximo, e [este] a abertura mais diminuta. A eloquência, uma virtude masculina na Antiguidade, implicava habilidade verbal, que Jesus utiliza aqui com efeito surpreendente" (MALINA; ROHRBRAUGH, 2002, p. 190). O recurso a esta composição obviamente atende aos propósitos de salientar uma dificuldade extrema, praticamente intransponível.

Isto é o que era no princípio: duas figuras deliberadamente postas em conexão, resultando em algo espantoso, ridículo ou risível. Justamente aí radica o poder da construção. Poder este que se desdobra em várias possibilidades. Percorro algumas: vou de Jesus - ou, mais precisamente, de um dito atribuído a ele - ao Corão. Lacunas, cortes e desvios não faltarão: o traçado não é sequencial, muito menos linear; é tortuoso, como são os caminhos da interpretação, especialmente de um dito assim explosivo como este. São mais de sete séculos que vão de Jesus à redação árabe do livro sagrado muçulmano; os fragmentos escritos recolhidos aqui para comentário são tomados como testemunhas de cenários sociorreligiosos múltiplos em que o referido dito ecoou poderosamente.

\section{DA IMAGEM AO PROVÉRBIO/PARÁBOLA}

Eventualmente pronunciado pelo andarilho galileu advindo de Nazaré - questão que aqui não discutirei -, o provérbio relacionando a imagem formada pela aproximação 
entre camelo e agulha com a possiblidade do ingresso de uma pessoa rica no Reino de Deus - para declará-lo praticamente inviável - deve ser considerado, sem mais, uma parábola, no sentido mais estrito da palavra, ou seja, considerada a distinção básica, que não costuma ser feita, em relação à "narrativa parabólica"; isso defende, recorrendo às classificações da retórica antiga, Berger (1998, p. 45) em seu trabalho sobre as formas literárias presentes no Novo Testamento, avançando para além de classificações tradicionais utilizadas correntemente na exegese. A feitura da parábola - expressa pela primeira vez por escrito, até onde conhecemos, no texto que hoje lemos em Mc 10,25 - assume um grande potencial de choque, na medida em que desafia uma presunção bastante arraigada de que a riqueza é de alguma forma expressão da bênção divina (MILLER, 1994, p. 37).

Neste sentido, talvez tenha mais razão Horsley que Crossan: enquanto este toma o dito em questão como um aforismo bem humorado, que "mostra, da parte de Jesus ou de Marcos, uma falta de ódio ou rancor contra os ricos"; diferentemente disso, postula que "a ideia de os ricos entrarem no Reino é mais do que impossível: ela é tão hilariante quanto a tentativa de fazer um camelo passar pelo buraco de uma agulha" (CROSSAN, 1994, p. 312), o exegeta estadunidense assevera que a declaração expressa "um humor camponês que apenas disfarça, ligeiramente, a hostilidade" (HORSLEY, 2014, p. 125; o destaque é meu). O dito supõe uma ambientação básica no mundo da gente despossuída, que subverte a atribuição de valor a esta condição marginal e mira à distância, com olhos e lábios críticos, a lógica de acumulação tão própria daqueles tempos (nem mais nem menos que outros, inclusive os nossos). E, para além de uma crítica que se imaginaria restrita à retórica, supõe o estabelecimento de laços de solidariedade horizontal para inventar o cotidiano, refazer as condições da sobrevivência, radicalizar e sustentar o distanciamento frente às engrenagens socioculturais sustentadas em lógicas que inviabilizam o ingresso no Reino (THEISSEN, 2002, p. 121).

Nas ponderações feitas no parágrafo acima está uma suposição que cabe explicitar, até porque vai na contramão de posições defendidas aqui e ali: estou pensando na vida própria que o provérbio/parábola pode ter tido antes e independentemente de ter vindo a ser inserido numa perícope - em lugar absolutamente central, adianto - que haveria de compor o Evangelho segundo Marcos. Seu caráter mordente a possibilita, 
e imaginemos em quantas e diversas situações este dito não pode ter sido repetido, entoado, gritado, na forma de desafio, ou de uma expressão ressentida, ou ainda de provocação... ${ }^{1}$ Outra observação a ser feita se refere à eventual presença, entre simpatizantes dos grupos de alguma forma ligados a Jesus que conservavam e passavam adiante ditos como este e outros de teor semelhante, de pessoas oriundas de setores sociais com algumas posses ou algo a mais: tal presença não foi capaz de intimidar ou minimizar a retumbância do dito em questão.

\section{O DITO E A TRADIÇÃO SINÓTICA}

É de responsabilidade da redação marcana a construção de uma perícope bastante complexa $(10,17-31)$, na medida em que articula vários parágrafos ao mesmo tempo relativamente autônomos ${ }^{2}$, mas muito bem articulados entre si: 1) vv. 17-22: Jesus e o homem rico; 2) vv. 23-27 (Jesus e os discípulos): a iniciativa de Jesus se associa bem ao que fora o desfecho decepcionante do diálogo entre ele e seu interlocutor; 3 ) vv. 28-31: no diálogo entre Pedro e Jesus a questão colocada pelo primeiro bem poderia se ligar diretamente ao primeiro momento, colocando-o em posição antagônica à adotada pelo interlocutor rico de Jesus.

O resultado é uma perícope que de modo geral tematiza o discipulado (BERGER, 1998, p. 229). A inserção do parágrafo ora intermediário parece indicar o reconhecimento, por parte da redação do evangelho, da centralidade da discussão sobre o tema, para além das situações pontuais extremadas (o interlocutor rico que não se dispôs a desfazer-se de seus bens e, por consequência, não seguiu a Jesus versus Pedro e seus companheiros que deixaram tudo e o seguiram). O dilema nãodiscípulo versus discípulo, com a radicalidade que o tema comporta, gira, no fim das

\footnotetext{
${ }^{1}$ Para Pesch (1982, p. 219) "o texto não deve ser entendido como um dito isolado, mas como uma hipérbole ligada a um contexto e a uma situação". A posição que adoto é contraposta a esta.

2 A narrativa conhecida como Evangelho segundo os hebreus, preservada apenas em fragmentos citados em obras de padres da Igreja como Orígenes e Jerônimo, confirma lateralmente o que aqui proponho: embora reproduza o teor central do que aqui estou identificando como primeiro parágrafo da perícope marcana (retomada com poucas alterações nos relatos mateano e lucano, como ainda comentarei), não prossegue com sua sessão central, a que aqui me interessa mais de perto; diferentemente disso, no apócrifo em questão a discussão prossegue, já que o interlocutor rico não aceita a convocatória de Jesus e protesta, o que exige deste último explicitar as razões pelas quais o apego às riquezas está na contramão da observância da Lei e dos Profetas. Para dados gerais sobre esta obra veja Edwards (2012; o fragmento a que me refiro, encontrado na versão latina do comentário de Orígenes ao Evangelho segundo Mateus, está na p. 126).
} 
contas em torno desta subunidade contida nos vv. 23-27. Dentro dela o provérbio parabólico sobre o qual aqui me debruço é decisivamente central. Ele soa, ao final, como o eixo fundamental em que o referido parágrafo se estrutura, bem como seu ponto alto:

A: vv. 23-24: centrados na dificuldade de entrar no reino de Deus colocada a quem tem riquezas - o espanto dos discípulos

\section{B: v. 25: a maior facilidade ao camelo passar pelo fundo da agulha} que a um rico entrar no reino de Deus

A': vv. 26-27: o estupor dos discípulos e a pergunta pela possibilidade/impossibilidade da salvação ${ }^{3}$

O aforismo é uma e outra vez contextualizado: 1) passa a compor diálogo que, por conta da radicalidade do dito atribuído a Jesus, se vê alongado por conta do manifesto desconforto dos discípulos em reação a ele; 2) tal diálogo por sua vez é apresentado em decorrência de uma circunstância específica, qual seja, o insucesso de Jesus em conseguir que uma pessoa possuidora de muitos bens deles se desfizesse para tornar-se discípulo seu. Sem pretender uma abordagem detalhada do resultado, faço apenas algumas pontuações. A primeira na verdade foi bem notada por Horsley (2010, p. 198): o dito, com sua carga e força, contribui para o desmonte, a que a perícope procede, da falsa segurança de quem julgava - como o interlocutor de Jesus - cumprir escrupulosamente os preceitos da Torá. Por outro lado, a elaboração marcana desloca o foco - não a força ou o impacto - do aforismo: se na configuração primeira que Ihe deu vida própria ele se mostra enraizado no mundo das margens sociais empobrecidas, no enredo evangélico em que foi inserido ele se presta a convocar gente de (algumas) posses que se sentem vinculadas a dinâmicas referidas à Torá a assumirem aquilo que, indo além da expressão de Theissen (2002, p. 284-285),

\footnotetext{
3 Na elaboração marcana "entrar no reino de Deus", presente nos dois primeiros parágrafos, se identifica com o "salvar-se", tema do terceiro. Veja os esquemas propostos por Myers (1992, p. 329), com os quais converge o que aqui se apresenta.
} 
conviria denominar "radicalização ética": deixar o que têm para se fazerem discípulos de Jesus. E isso sem que o dito perca nada de sua contundência: da dificuldade que se põe a alguém de posses entrar no reino de Deus (v.23) se chega, com o dito do v.25, à quase impossibilidade de que isto ocorra. ${ }^{4}$

A essa altura é preciso notar, antes de passar às reelaborações do relato marcano, que não deixou de existir quem pretendesse identificar uma intenção redacional que, ao fim e ao cabo, pretendesse minimizar a força e o impacto do lógion (termo grego que significa "sentença", "dito") que aqui comento. Kelber (1974, p. 88), por exemplo, sugere que o dito teria a finalidade de mostrar que as portas do Reino estariam impossibilitadas de serem removidas não pelos ricos especificamente, mas pelos discípulos em geral! O evangelista não estaria preocupado com o antagonismo irreversível entre posse de riquezas e posses do Reino, mas em indicar os desafios de absoluta exigência colocados a todas as pessoas para o ingresso no Reino, algo de que o dito "exagerado" sobre o camelo e a agulha serviria de poderosa ilustração. Não é o que o todo da perícope marcana indica, e a própria reação de Pedro no v.28 o salienta suficientemente: o caminho do discipulado implica radical ruptura com os códigos de honorabilidade daqueles tempos e conjunturas (e não só deles!), de que a riqueza é uma das mais destacadas expressões. Por outro lado, uma exegese e uma hermenêutica que, intencionalmente ou não, acabam por neutralizar o poderio ácido e crítico de um lógion como este que lemos em Mc 10,25 são processos de bem longa duração, de que alguns lances aparecerão no transcorrer deste artigo.

Passo então aos textos do Evangelho segundo Mateus e do Evangelho segundo Lucas, apenas para salientar que a construção em três parágrafos acima identificada é reproduzida neles (Mt 19, 16-30; Lc 18, 18-30), embora de maneira mais concisa, com ajustes aqui e ali que não comprometem a estrutura geral e a linha fundamental de desenvolvimento da perícope (veja, para o caso do texto lucano, BAILEY, 1995, pp. 342-344). O provérbio aqui em foco continua a comparecer com toda a sua contundência; e talvez se possa sugerir, no caso da elaboração Lucas-Atos, que a

\footnotetext{
${ }^{4}$ Esta contundência, a despeito de tantas vicissitudes dos processos históricos, logrou alcançar nossas terras; é para o que aponta episódio que se conta de Antonio Conselheiro, este "radical itinerante" do sertão por quase vinte anos: andando pelo Sergipe nos idos de 1872-74, ele teria "aconselhado", recorrendo "à parábola 'da passagem do camelo pelo fundo da agulha", um certo José de tal (segundo outra fonte, Joaquim da Macota) a deixar seus bens e seguir rumo à "terra prometida" (OLIVEIRA, s/d).
} 
perícope que tem como protagonista Zaqueu, um "chefe" de arrecadadores de impostos, que não demorará muito a aparecer na sequência da narração (Lc 19,1-10), se mostre como desdobramento, ilustrado numa pessoa que se antecipou a agir na direção do que tinha sido a indicação de Jesus ao homem que o procurara, também ele designado como "chefe". É a posição esposada, entre outros, por Fitzmyer (2005, p. 58), na contramão de intérpretes que tomam tal episódio como uma atenuação, que atenderia aos propósitos da redação lucana, das exigências colocadas pelo aforismo aqui em questão (posição adotada, entre outros por Bazzana [2019]).

E talvez baste, para não minimizar a força do que é declarado nos propósitos de Zaqueu, pensar a contabilidade pessoal daquele chefe de publicanos no dia seguinte ao da efetiva realização daquilo com que ele se comprometeu... A redação da obra tinha certamente a expectativa de que, como teria ocorrido, segundo ela, no ambiente da primeira comunidade de Jerusalém (At 2,44-45; 4,32-35), também naquelas em que ela se dava, marcadas pela convivência entre ricos e pobres, que certamente era fonte de não poucas tensões (semelhantes às que se vislumbram da leitura das cartas paulinas aos coríntios, por exemplo; veja o precioso comentário de Comblin a este respeito [1989, pp. 31-37]), houvera mais e mais Zaqueus a sinalizar que a força do evangelho era suficiente para abalar valores, práticas e relações há tanto enraizados... Seja como for, ao narrador lucano é claro que o movimento anunciado por Zaqueu é um dos feitos decisivos alcançados por Jesus ao final de sua longa jornada na direção de Jerusalém: ele conseguiu do "chefe" que encontrou em Jericó o que não lograra junto ao outro "chefe" que não fazia muito o havia abordado.

\section{CAMELOS E AGULHAS, PÉS DESCALÇOS E CARDOS}

A história que o dito atribuído a Jesus vai fazendo tem, obviamente, nos evangelhos que viriam a ser incluídos no Novo Testamento marcos decisivos. Mas eles não foram os únicos. Isso no-lo evidencia o formato que ele assume num escrito produzido na primeira metade do século II. Trata-se d'O pastor de Hermas, obra muito considerada nos tempos seguintes a seu surgimento, a ponto de constar inclusive no rol de livros considerados canônicos em códices tão significativos como o Sinaítico. ${ }^{5}$ Seu autor,

${ }^{5}$ O Códice Sinaítico (assim denominado por ter sido encontrado no século XIX, nas dependências de um mosteiro situado nas imediações do que tradicionalmente é tido como o monte Sinai) foi 
um ex-escravo, é membro de alguma comunidade seguidora de Jesus em Roma e escreve em grego (para um criativo comentário à obra, HOORNAERT, 2002). Sem que possa entrar aqui em detalhes, assumo o caminho aberto por alguns estudiosos, que sustentam que a obra, ao recolher memórias relacionadas a Jesus, o faz sem recorrer aos evangelhos canônicos (CROSSAN, 1994, p. 469). Para ilustrar a questão específica que me interessa aqui, recolho a seguinte passagem, extraída do parágrafo 97:

\begin{abstract}
Os fiéis que vieram da terceira montanha: a coberta de espinhos e cardos, são estes: alguns deles são ricos e outros enredados em numerosos negócios. Os cardos simbolizam os ricos, e os espinhos são os que se enredaram em múltiplos negócios. [...] Os ricos dificilmente se ligam aos servos de Deus, porque temem que alguém Ihes peça alguma coisa e, por isso, dificilmente entrarão no Reino de Deus. Assim como é difícil andar descalço sobre os cardos, também o é para eles entrar no Reino de Deus (O pastor, 1995, p. 262; o destaque é meu).
\end{abstract}

Como se trata de texto pouco conhecido, vale situá-lo na trama mais geral do livro. Trata-se de parte de amplo comentário, em perspectiva alegorizante, a uma visão que o escritor apresenta ter tido, visão de doze montanhas em torno a uma planície, cada qual delas com características peculiares, e um sem-número de outros itens a constituírem um quadro amplamente complexo. Tais montanhas se associavam às doze tribos de Israel e "são doze nações", compostas cada uma delas de "fiéis". Se os que vêm da primeira montanha são blasfemos e estão destinados à morte, e os da segunda são hipócritas aos quais é possível a penitência, os que vêm da terceira montanha se dividem, como se leu, entre "ricos" e homens "enredados em numerosos negócios". E enfim se chega ao ponto: é em relação a estas pessoas que se registra o comentário dentro do qual comparece uma formulação que parece remeter ao dito atribuído a Jesus, este que é objeto aqui de minha atenção. Eis o que pode ter ocorrido, na avaliação sugestiva de Crossan (1994, p. 312):

Hermas talvez conhecesse o aforismo completo [que associa camelo/fundo da agulha e a quase impossibilidade de uma pessoa rica entrar no Reino de Deus], mas, por já trabalhar com a metáfora de os ricos não poderem caminhar entre os espinhos e cardos [...], preferiu não utilizar toda a sentença [...].

confeccionado em meados do século IV e é possivelmente o mais antigo exemplar, chegado a nossos dias, a conter a totalidade dos textos do Novo Testamento, incluído aí O pastor de Hermas.

Paralellus, Recife, v. 12, n. 30, mai./ago. 2021, p. 449-467 
É possível, mas talvez se possa dizer mais. Não se trata apenas de preferência. A mudança das imagens - de camelo/agulha para pés/espinhos e cardos - desloca sutilmente as condições colocadas aos ricos, de uma quase impossibilidade a uma dificuldade, mesmo que grande. Sem que se perceba isso não se entende a continuação do texto d'O pastor, no mesmo parágrafo:

Todavia, para todos esses ["ricos" e "enredados em numerosos negócios"] existe possibilidade de penitência, com a condição de que seja logo, para recuperar nesses dias o que não fizeram no passado e assim praticar alguma coisa boa.

Evidencia-se então que começa aqui, pelo menos até onde se conhece, um processo pelo qual se minimizará o potencial categórico do dito que os evangelhos sinóticos atribuem a Jesus. Isto é coerente com a visão geral encontrada n'O pastor a respeito da relação entre ricos e pobres: o livro "apresenta denúncia contra os ricos, mas o julgamento deles é condicional, sendo essencialmente um convite ao arrependimento e não uma condenação à destruição" (ADRIANO FILHO, 1998, p. 144). Em nome da coerência com esta posição o autor do livro optou por alterar a imagem com a qual a dificuldade colocada às pessoas ricas é associada. Em outros testemunhos o dito será confrontado diretamente.

\section{QUANDO O FUNDO DA AGULHA COMEÇA A SE ALARGAR}

É nas obras de Clemente de Alexandria, atuante nos últimos anos do século Il e nos inícios do seguinte que se evidencia pela primeira vez a referida confrontação. Afinal de contas, este influente líder, mestre dotado de conhecimento do legado filosófico grego em amplitude até então inédita nos vários segmentos que de alguma forma se pretendiam vinculados a Jesus, não teme explicitar seu desconforto diante dos ditos sobre ricos e riquezas atribuídos a Jesus, particularmente a cena resultante da elaboração marcana (que é aquela que com ele parece operar). É indisfarçável, apesar de ressalvas em contrário, seu incômodo com o dito sobre o camelo e a agulha ilustrando as dificuldades dos ricos em relação ao Reino de Deus; eis uma palavra de Jesus a ser domada, extravagante que é (HOEK, 2008, p. 72): "O camelo que passa pelo caminho reto e estreito diante do homem rico deve ter algum significado superior", assim se lê no texto que ficou conhecido em seu título latino Quis dives salvetur? (Qual 
rico se salvará?), em seu tópico 26,7 (D’ALEXANDRIE, 2011, p. 171). Ou seja, qualquer significado que contorne o óbvio. O caminho será o da interpretação alegórica: o convite é para que alguém não se detenha, paralisado, diante do texto, mas que avance para além dele, no sentido de, ao final, aliviar-se perante sua contundência enfim atenuada; assim se lê em 2,2:

De fato, porque eles só escutaram rápida e distraidamente as palavras do Senhor de que será mais fácil para um camelo passar pela abertura de uma agulha de costura do que para um homem rico alcançar o Reino dos Céus, alguns, desesperados com o pensamento de que perderão suas vidas, abandonaram-se totalmente ao mundo e se agarraram a esta vida como a única que Ihes resta. Assim, eles se desviaram mais do Caminho que leva até lá, sem continuar a se perguntar quem são os ricos de quem nosso Senhor e Mestre fala, nem como o que é impossível para um homem pode se tornar possível (D'ALEXANDRIE, 2011, p. 105).

A exposição de Clemente não está motivada pela força da palavra de Jesus, mas pela reação de espanto dos discípulos ("quem poderá salvar-se?"), devidamente ajustada por ele em vistas a seus propósitos, que têm a ver diretamente com o público que tem em mente: "qual rico se salvará?" Ela trata "de reduzir a suas justas proporções a perturbação sentida pelos ricos [da comunidade] ao ouvirem o episódio evangélico" do qual o lógion em questão é eixo; Clemente "quer dissipar, ou ao menos atenuar, a tentação de desespero e o desengajamento moral daí decorrentes" (NARDI, 2011, p. 16). ${ }^{6}$

Ainda uma notação: no texto de Clemente, que se apresenta como uma relativamente extensa abordagem da perícope marcana no seu todo (ou seja, aquilo que vai do v. 17 ao 31 do capítulo 10), apenas três vezes o dito do camelo e da agulha é mencionado, e uma delas se dá quando o texto evangélico é transcrito: as outras duas são as passagens acima recolhidas e comentadas. Não é temerário arriscar que este filósofo bem gostaria de não ter de enfrentar a referida sentença. Por outro lado, ela é a razão de ser, em última instância, de suas elucubrações. Para minimizar o quanto possível seu impacto ele tratará tanto de problematizar a compreensão de riqueza e de pobreza, bem como de estabelecer um impasse, caso o texto em questão seja lido

\footnotetext{
${ }^{6}$ É interessante notar como Nardi (2011, p. 13) insiste no "desespero" que o alexandrino parecia divisar no público com o qual interagia e tratava de instruir: o texto em questão seria, então, "uma espécie de antídoto" a ele. Para a contextualização sócio-eclesial da leitura de Clemente, a exposição de Hoornaert (1986, pp. 128-133) permanece válida em suas linhas gerais.
} 
na radicalidade que se desdobra de sua letra, visto que, no entender dele, outras passagens dos evangelhos (por exemplo, Lc 16,9) sugerem um possível bom uso das riquezas. Mas principalmente ele arremete contra os pobres que, por terem de labutar para suprir suas necessidades, não encontram tempo e condições para se engajarem em coisas mais elevadas. Efetivamente, os termos beiram a grosseria contra quem sofre no cotidiano para apenas sobreviver, mesmo que, mais uma vez, o foco de Clemente esteja na gente possuidora, que eventualmente quisesse operar na direção daquilo que Jesus apontara a seu interlocutor; veja o tópico 12,4 e 5:

Pois, deve-se dizer, mesmo que se tenha sido aliviado do fardo dos
seus bens, ainda se pode ter o desejo e o gosto pelo dinheiro; pode-
se rejeitar o uso dele, mas, diante da privação e do arrependimento do
que se deixou ir, experimenta-se um duplo sofrimento, devido à
ausência do que era útil e à presença do arrependimento. De fato,
carecer do necessário para viver é inevitavelmente ter o coração
quebrado e se afastar do essencial, na tentativa de obtê-lo,
independentemente do método ou fonte. Clemente consegue a proeza de inverter a significação do dito que os evangelhos sinóticos atribuem a Jesus já que, pelo que se lê, é à gente empobrecida ou que se fez pobre que as dificuldades de acesso ao essencial se colocam de maneira mais incisiva. Não se deixe de notar ainda a apenas parcialmente disfarçada suspeita do escritor quanto aos meios pelos quais as pessoas despossuídas do necessário viabilizam sua sobrevivência cotidiana...

Por outro lado, no tópico 3,5 Clemente assevera: "mesmo no meio das riquezas desta terra, absolutamente ninguém deve proclamar-se privado das recompensas prometidas pelo Salvador, se pelo menos ele é fiel e vê a grandeza do amor de Deus pela humanidade!" (D'ALEXANDRIE, 2011, p. 109). É que, para o autor, "as operações internas da alma são mais importantes do que a condição humana de pobreza ou riqueza" (HOEK, 2008, p. 75). As portas da comunidade eclesial estão escancaradas às pessoas de posses; agora que veem convenientemente alargado o fundo da agulha e diminuído o tamanho do camelo, poderão operar em termos de filantropia - palavra cara a Clemente; afinal de contas, é muito mais útil que alguém dotado de posses, sem se sentir atormentado por as ter ou por as ajuntar, se ponha como teriam feito, segundo o autor, Levi, Mateus e Zaqueu ${ }^{7}$ - a ajudar a quem se

${ }^{7}$ Clemente, assim como fará Orígenes, considera Mateus e Levi personagens distintos. 
deve: "Que possibilidade de compartilhamento haveria entre os homens se ninguém tivesse nada?" (é o que se lê em 13,1: D’ALEXANDRIE, 2011, p. 135).

Clemente operou no terreno do significado do dito evangélico e da perícope da qual ele é núcleo, como se viu; no que vem a seguir encontraremos também intervenções no âmbito dos significantes.

\section{DO CAMELO À CORDA}

Dando um salto de dois séculos, uma vez mais abordo cenários mediterrâneos ocidentais, chegando aos tempos de Agostinho, no início dos 400. O ambiente é outro: Constantino já havia vindo e passado, Teodósio já convertera o cristianismo em religião oficial do moribundo império romano. É hora de consolidar o lugar do cristianismo na sociedade em moldes que logo o farão cristandade. Mas apenas saliento algo, que nem de longe há de ser tomado como novidade: no âmago da chamada "controvérsia pelagiana" 8 não deixa de comparecer a discussão ensejada em torno do movimento do camelo pela agulha; enquanto Pelágio defendia que "um rico que permaneça na posse das suas riquezas não pode entrar no Reino" (em adoção evidente do dito de Mc 10,23), o bispo de Hipona garantia que "se os ricos forem virtuosos" não precisam ter preocupações: "quando chegar o último dia estarão na Arca". O princípio pelagiano "acaba com os ricos e deixará de haver pobreza" é substituído pelo de seu opositor: "acaba com a pobreza e a riqueza não te trará prejuízo" (citações recolhidas de BRUNI, 2020). Uma posição como esta, que obviamente não é exclusiva de Agostinho, embora difira enormemente da de contemporâneos seus como Jerônimo, talvez ajude a entender que em manuscrito contendo texto atribuído a Cirilo de Alexandria, escritor desta mesma época, a passagem bíblica aqui em questão seja citada com a palavra "corda" em lugar de "camelo" (kámilon em lugar de kámelon, em grego). ${ }^{9}$ A mesma alteração aparecerá

\footnotetext{
${ }^{8}$ Expressão com que se costuma designar o acalorado debate, nos inícios do século $\mathrm{V}$, em torno das posições esposadas pelo bispo de Hipona Agostinho e pelo monge Pelágio a respeito das condições (ou da falta delas) de o ser humano alcançar a salvação escatológica por seus próprios méritos e esforços.

${ }^{9}$ Isto pode ser conferido nos aparatos das edições críticas do Novo Testamento disponíveis. Para nota em relação a este ponto específico, veja Omanson (2010, p. 32). Fitzmyer (2005, p. 31) informa, porém, que já em Orígenes esta alteração pode ser constatada. No caso de Cirilo, eis o que lhe é atribuído: "Por 'camelo' não se quer dizer do ser vivo, da besta de carga, mas da corda grossa com que marinheiros amarram suas âncoras" (citado em REYNOLDS, 2019, p. 48).
} 
em alguns testemunhos manuscritos tardios. Estaria em curso naqueles tempos movimento cujo resultado ganharia eco em tantos e tantos ambientes eclesiais, qual seja, a diminuição da espessura daquilo que deveria atravessar um fundo de agulha que se apresenta cada vez mais alargado? Seja como for, é bom notar que tal movimento, se existia, operava na contramão de outro que pode bem ser representado por um sonho relatado por Melânia (conhecida como "a jovem"), ela que, com a idade de vinte e dois anos se viu convocada, junto com seu marido Piniano, à vida ascética, o que exigia a disposição em despojar-se da fortuna em posse do casal. Por volta de 404-405 (portanto, nos tempos de Agostinho já bispo em Hipona e de Cirilo em Alexandria), a força do dito evangélico era suficiente para produzir pesadelos ao casal (!):

Uma noite [Melânia diz] fomos dormir, muito aborrecidos, e vimos nós mesmos, ambos, passando por uma fenda muito estreita em um muro. Fomos agarrados pelo pânico pelo espaço apertado, de modo que parecia que estávamos prestes a morrer. Quando atravessamos a dor daquele lugar, encontramos um enorme alívio e alegria indescritíveis (Gerôncio, citado por BROWN, 2012, p. 291).

Pelágio, elogiador do caminho adotado pelo casal mencionado, não se furtava a reconhecer a impossibilidade absoluta apontada pelo dito do camelo e da agulha. Não são possíveis subterfúgios, nem mesmo o caminho de buscar uma agulha muito grande e um camelo suficientemente pequeno (veja BROWN, 2012, p. 319). Já Agostinho preferia fazer retoques, se não ao dito, ao sentido imediato que dele se depreende, indicando tanto distorções que dele podem ser feitas como a existência de outros fatores a serem considerados quanto ao ingresso no Reino de Deus. Ele tanto alerta uma pessoa pobre e maltrapilha que tenderia, ao ouvir o dito evangélico, a locupletar-se de sua indigência e a rir-se do futuro escatológico de alguém poderoso que a violenta e oprime, quanto "louva" a arrogância do rico que, em vez de castigar seu escravo de forma selvagem, repreende-o com palavras duras e assim o mantém sob controle (veja textos de Agostinho e comentários em BROWN, 2012, p. 351). Não é preciso notar que não foi apenas na posição quanto ao livre-arbítrio e à graça divina que Agostinho se impôs a Pelágio... 


\section{MESMA IMAGEM, OUTRA DIREÇÃO}

Neste último tópico volto em definitivo ao mal chamado Oriente Médio; não em busca de comentadores individuais de passagens de evangelhos enfim canonizados, ou de impactos delas na vida desta ou daquela pessoa. Procuro ainda outras formas de impacto que o dito sobre o camelo e agulha possa ter produzido. $E$ as encontro num testemunho que a muitos pareceria improvável: uma passagem de um texto que hoje configura o Corão muçulmano. Sem que possa discutir os motivos de eventual surpresa, saliento apenas dois pontos: a) os materiais que constituem o Corão deitam raízes profundas nas vicissitudes e complexidades sociais, políticas e religiosas experimentadas em regiões para além da Península Arábica nos séculos da chamada Antiguidade tardia, de modo particular no mundo dos monoteísmos, em que as fronteiras entre judaísmo(s) e cristianismo(s) eram muito pouco definidas e traços decisivos do que mais tarde se chamaria islã se manifestavam, latentes (GONZÁLEZ FERRÍN, 2018, pp. 215-305); b) o processo de constituição do Corão enquanto livro único, referência para a constituição de uma identidade religiosa específica, a saber, o islã, é obra de pelo menos séculos de coletas, compilações e decantações, ultrapassando em muito o exíguo tempo de suas décadas e meia sugerido pela tradução muçulmana e aceito quase unânime no mundo acadêmico (VASCONCELLOS, 2019, pp. 378-391). É a partir destes pressupostos que devem ser consideradas as óbvias relações de intertextualidade envolvendo o dito do camelo/fundo da agulha referido nos evangelhos sinóticos e a seguinte passagem que hoje se lê na sura 7 do Corão, em sua aleia $40^{10}$ :

Por certo, aos que desmentem nossos sinais e, diante deles, se ensoberbecem, não se lhes abrirão as portas do céu nem entrarão no paraíso, até que o camelo penetre no fundo da agulha.

É indiscutível a relação com o dito que nos evangelhos sinóticos se atribui a Jesus. Mas logo chamam a atenção duas notas: a) a advertência tem em mente "pessoas que desmentem nossos [de Deus] sinais" e que "se ensoberbecem", e não pessoas ricas; b) em lugar de "entrar no Reino de Deus" se fala de "entrar no paraíso (com o uso de uma palavra que mais imediatamente significa "jardim") e abertura das portas

10 Sura e aleia correspondem, grosso modo, no caso do Corão, àquilo que designam na Bíblia capítulo e versículo, respectivamente. 
do céu. Presto atenção aqui à primeira delas: haveria um deslocamento de foco daquilo que se lê nos evangelhos sinóticos e o que se proclama no que veio a ser uma sura constitutiva do Corão? Os alvos seriam distintos numa proclamação e outra? E qual o sentido de eventual distinção? Galadari (2018), no intuito de qualificar o que toma como destacado exemplo de "interpretação corânica dos evangelhos", desenvolve dois caminhos de abordagem do problema, que aqui posso apenas identificar. Primeiramente, a elaboração do texto em questão, hoje corânico, não depende diretamente dos evangelhos sinóticos que conhecemos, mas de cópias do Diatessaron, uma narração continuada composta numa espécie de harmonia dos evangelhos que rumavam para serem "canonizados", isto em fins do século II e obra de Taciano; esta obra foi de amplo uso no âmbito das igrejas de fala siríaca; ora, neste escrito a chamada parábola do "rico insensato" que hoje lemos em Lc 12,16-21, antecede de forma imediata o episódio do encontro de Jesus com a pessoa que decide não o seguir por conta de suas posses, razão do lógion atribuído a Jesus e de que estou aqui perscrutando alguns rastros. Não parece haver dúvida, portanto, de que o texto evangélico típico daquelas paragens remete, nas passagens assim combinadas, a pessoas que, justamente pelas posses que têm, estão distantes do reino de Deus.

O segundo elemento a ser destacado é que nos textos que hoje formam o Corão e que conhecemos apenas em árabe (mas para os quais é convém pensar um pano de fundo "siro-aramaico", como quer Luxenberg [2007]), há um jogo de palavras possível entre os termos que significam "riqueza" e "arrogância". Isto permite a Galadari (2018, p. 86) sugerir que, na passagem em questão, o recurso "corânico" à imagem do camelo/fundo da agulha indique, de um lado, uma atenção ao dito evangélico e, de outro, uma interpretação dele: o "rico" dos textos do Diatessaron é uma ilustração para "arrogante"; se são possíveis exceções no caso de gente possuidora de bens a que o ingresso no reino de Deus não estaria vedado, elas - as exceções - não se colocariam no caso de pessoas arrogantes que desconhecem os sinais divinos. Ter-se-ia operado uma "torção" (REYNOLDS, 2019, p. 45) ou uma "rearticulação dogmática" (ELBADAWI, 2014, p. 188) que então direciona o dito de advertência a pessoas ricas à temática do desprezo dos sinais de Deus, tema característico de muitas passagens que hoje compõem suras corânicas. Reescreve-se, então, a sentença tradicional e se 
a reinsere em novo cenário, em que marcas da apocalíptica dão o tom predominante. ${ }^{11}$

\section{CONCLUSÃO}

Nem foi possível abordar outros eventuais rastros trilhados pela imagem associando camelo e fundo de agulha de cuja composição gerou o impactante dito atribuído a Jesus nos evangelhos sinóticos - e no Diatessaron, acrescente-se por justeza. No entanto, do percurso feito, ao final dele, desdobram-se ao menos duas observações conclusivas. Primeiramente, a composição da referida imagem resultou em algo de inimaginável potencial, de que é testemunha também o dito atribuído a um rabino que fala em páginas do Talmude babilônico; ao garantir que as pessoas não sonham situações absurdas, ele afirma diz: "um homem nunca vê em sonhos uma palmeira de tâmara feita de outro, ou um elefante passando pelo fundo de uma agulha" (citado em BAYLEY, 1995, p. 353). Deixando de lado a absoluta imperícia deste mestre judeu em assuntos oníricos, fica o registro de mais um modo como a imagem que operou como eixo na confecção deste artigo repercutiu em mais um destes ambientes experimentados por filhos e filhas de Abraão, em associação a outro tema que aqueles que foram objeto de atenção nas linhas acima.

E se impõe uma segunda observação: tanto a visão d'O pastor e as elucubrações de um Clemente ou de Agostinho, como as alterações textuais de que faz uso um Cirilo e ainda o deslocamento de perspectiva apontado pela construção do texto que hoje lemos no Corão, tudo isto indica como a associação da imagem absurda de um camelo atravessando o fundo de uma agulha com a impossibilidade de uma pessoa rica entrar no reino de Deus produziu impactos insuportáveis na quase totalidade dos ambientes que se defrontaram com a sentença atribuída a Jesus. Das reações a ela se definiram não poucos contornos e percepções de mundo nas gerações que se identificaram como herdeiras do legado vinculado a sua pessoa e atividade. Com isto se pode constatar, em cenários variados tanto em termos de tempo como de espaço, o poder que textos têm em deixar rastros, inspirando posicionamentos de sujeitos e comunidades, desafiando convenções e seguranças estabelecidas. E, de modo muito

${ }^{11} \mathrm{E}$ também no interior da tradição exegética muçulmana se discutiu se se estaria, na passagem em questão, diante de um camelo ou de uma corda grossa (veja RIPPIN, 1980).

Paralellus, Recife, v. 12, n. 30, mai./ago. 2021, p. 449-467 
particular: o percurso proposto permite desafiar fronteiras artificiais que distanciam grupos e tradições que apenas simbioticamente se desenvolveram do modo como o fizeram: refiro-me aos modos como cristianismo e islã se configuraram, entre interações e diferenciações.

\section{REFERÊNCIAS}

ADRIANO FILHO, José. "O pobre e o rico em Tiago e no Pastor de Hermas". In: Revista de Interpretação Bíblica Latino-Americana. Petrópolis/São Leopoldo, 1998. n.31, pp. 143-157.

BAILEY, Kenneth. As parábolas de Lucas. 3 ed., São Paulo: Vida Nova, 1995.

BAZZANA, Giovanni B. "From Thesauroi to Purses: Wealth and Poverty between $Q$ and Luke". In: VERHEYDEN, Joseph and KLOPPENBORG, John S. Luke on Jesus, Paul and Christianity: What did he really know? Leuven: Peeters, 2019, pp. 193-217.

BERGER, Klaus. As formas literárias do Novo Testamento. Tradução de Fredericus Antonius Stein. São Paulo: Loyola, 1998.

BROWN, Peter. Through the eye of a Needle: Wealth, the Fall of Rome, and the Making of Christianity in the West, 350-550 AC. Princeton/Oxford: Princeton University, 2012.

BRUNI, Luigino. "O buraco da agulha tornou-se grande" (25/01/2020). Disponível em: <https://www.luiginobruni.it/br/ok-ok/o-buraco-da-agulha-tornou-segrande.html>. Acesso em 19 mai 2021.

COMBLIN, José. Atos dos apóstolos: vol. I: 1-12. Petrópolis: Vozes/Imprensa Metodista/Sinodal, 1988.

CROSSAN, John Dominic. O Jesus histórico: a vida de um camponês judeu do Mediterrâneo. Tradução de André Cardoso. Rio de Janeiro: Imago, 1994.

D'ALEXANDRIE, Clément. Quel riche sera sauve? Paris: Cerf, 2011 (volume preparado por Carlo Nardi e Patrick Descortieux).

EDWARDS, James R. "The Hebrew Gospel in Early Christianity". In: MCDONALD, Lee Martin and CHARLESWORTH, James H. (org.) "Non-canonical" Religious Texts in Early Judaism and Early Christianity. London/New York: T\&T Clark, 2012, pp. 116152.

EL-BADAWI, Emran lqbal. The Qur'an and the Aramaic Traditions. Abingdon: Routledge, 2014.

FITZMYER, Joseph A. El evangelio según Lucas IV. Tradução de Dionisio Míguez. Madrid: Cristiandad, 2005.

GALADARI, Abdulla. "The Camel Passing through the Eye of the Needle: a Qur'anic Interpretation of the Gospels". In: Ancient Near Eastern Studies. Leuven, 2018. n. 55, pp. 77-89. 
GONZÁLEZ FERRÍN, Emilio. A angústia de Abraão: as origens culturais do judaísmo, do cristianismo e do islamismo. Tradução de Pedro Lima Vasconcellos. São Paulo: Paulus, 2018.

HOEK, Annewies van den. "Widening the Eye of the Needle". In: HOLMAN, Susan R. (org.) Wealth and Poverty in Early Christian Church and Society. Grand Rapids: Baker, 2008, pp. 67-75.

HOORNAERT, Eduardo. A memória do povo cristão. Petrópolis: Vozes, 1986.

HOORNAERT, Eduardo. Hermas no topo do mundo: leitura de um texto cristão do século II. São Paulo: Paulus, 2002.

HORSLEY, Richard A. Jesus e a espiral da violência: resistência judaica popular na Palestina romana. Tradução de Monika Ottermann. São Paulo: Paulus, 2010.

HORSLEY, Richard A. Jesus and the Politics of Roman Palestine. Columbia: University of South Carolina, 2014.

KELBER, Werner H. The Kingdom in Mark: a New Place and a New Time. Philadelphia: Fortress, 1974.

LUXENBERG, Christoph. The Syro-Aramaic Reading of the Koran: a Contribution to the Decoding the Language of the Koran. Berlin: Verlag Hans Schiler, 2007.

MALINA, Bruce e ROHRBRAUGH, Richard L. Los evangelios sinópticos y la cultura mediterránea del siglo I. Tradução de Victor Morla Asencio. Estella: Verbo Divino, 2002.

MILLER, Robert [ed.] The Complete Gospels. San Francisco: HarperCollins, 1994.

MYERS, Ched. O evangelho de são Marcos. Tradução de I. F. L. Ferreira. São Paulo: Paulus, 1992.

NARDI, Carlo. “Introduction”. In: D'ALEXANDRIE, Clément. Quel riche sera sauve? Paris: Cerf, 2011, pp. 9-71 (volume preparado por Carlo Nardi e Patrick Descortieux).

OLIVEIRA, Itamar Freitas de. "No rastro de Conselheiro". Disponível em: <http://www.infonet.com.br/ canudos/roteiro.htm>. Acesso em 09 mar 2003.

OMANSON, Roger L. Variantes textuais do Novo Testamento: análise e avaliação do aparato crítico de "O Novo Testamento Grego". Tradução de Vilson Scholz. Barueri: Sociedade Bíblica do Brasil, 2010.

Pastor de Hermas. In: Padres apostólicos. São Paulo: Paulus, 1995, pp. 159-274. PESCH, Rudolf. /l vangelo di Marco: parte seconda. Tradução de Marcello Sofritti. Brescia: Paideia, 1982.

REYNOLDS, Gabriel S. "Biblical Turns of Phrase in the Quran". In: ELIAS, Jamal J. and ORFALI, Bilal (ed.) Light upon Light: a Festschrift Presented to Gerhard Böwering by his Students. Leiden: Brill, 2019, pp. 45-69.

RIPPIN, Andrew. "Qur'ān 7,40: 'Until the Camel passes through the Eye of the Needle’”. In: Arabica. Leiden, 1980. n. 27, pp. 107-113. 
STEGEMANN, Ekkehard W. e STEGEMANN, Wolfgang. Historia social del cristianismo primitivo. Los inicios em el judaísmo y las comunidades cristianas em el mundo mediterráneo. Tradução de Miguel Montes. Estella: Verbo Divino, 2011.

THEISSEN, Gerd. La religión de los primeiros cristianos. Tradução de Manuel Olasagasti Gaztelumendi. Salamanca: Sígueme, 2002.

VASCONCELLOS, Pedro Lima. "De trajetórias que fizeram uma sura do Corão a repensar as origens do islã". In: Araucaria. Revista Iberoamericana de Filosofía, Humanidades y Relaciones Internacionales. Sevilla, 2019. n. 41, pp. 378-391. 